\title{
Morphological and Biological Variability of Different Isolates of Paecilomyces lilacinus against Root Knot Nematode in Tomato
}

\author{
B. G. Anusha*, Shripad Kulkarni and S. I. Harlapur
}

Department of Plant Pathology, College of agriculture science Dharwad, University of Agriculture Science, Dharwad, Karnataka, India

*Corresponding author

\section{A B S T R A C T}

\begin{tabular}{|l|}
\hline Ke y w or d s \\
Paecilomyces \\
lilacinus, \\
Bioefficacy and \\
variability. \\
\hline Article Info \\
\hline Accepted: \\
10 September 2017 \\
Available Online: \\
10 October 2017 \\
\hline \hline
\end{tabular}

The modern intensive Agricultural practices have considerably raised the output but created problems like land and environmental degradation and pollution. Besides, this contamination of food products and pesticidal residue in food has caused much panic among the consumers and also the producers. Hence, it is necessary to find out innovative and suitable alternative technology like biological control of pests and diseases. Recently, Paecilomyces lilacinus based different formulations are used for the control of nematode diseases, which is economical, ecofriendly and sustainable in the long run. Among the different bioagents used in the tomato ecosystem, P. lilacinus is extensively used as seed dressing bioagent against many soil borne diseases, however, its usage against foliar diseases is limited. Isolates significantly varied with respect to colony characters, sporulation of the isolate and conidial characters. Based on the colony characters observed Tadakoda isolate had initially white colony later it turned to pinkish smooth colony. It produced single, round to oval conidia on phailides which sporulated early.

\section{Introduction}

Tomato (Lycopersicum esculantum L.) is one of the most popular vegetable crops grown in the world, next to potato. It is used as a fresh vegetable and processed and canned as a paste, juice, sauce, powder or as a whole (Barone and Frusciante, 2007). The ripe fruits are good source of vitamin A, B and C which add wide varieties of colour and flavour to the food.

Recently, it started gaining more medicinal value because of the antioxidant property because of ascorbic acid and lycopene content (Anon., 2000). Hence tomatoes are called as poor man's apple (Rick, 1969).
Tomatoes offer significant nutritional advantages, including providing a significant source of dietary lycopene, $\beta$-carotene, carotenoids, vitamin $\mathrm{C}$, potassium, fiber, color, flavor and antioxidant properties in a low energy dense food (Britt and Kristin, 2011 and Rani and Khetarpual, 2009).

Several human studies indicated a relationship between a high intake of tomato products and a decreased risk of several types of cancer, atherosclerosis and cardiovascular diseases (Cecilia et al., 2010). Recently, this crop is recognized as a model for plant-pathogen interactions (Arie et al., 2007). 
Many factors operate in successful cultivation as well as marketing of quality tomatoes of which diseases play an important role. Several diseases appear on tomato caused by fungi, bacteria, viruses, nematodes and abiotic factors (Balanchard et al., 1992). Among the nematode diseases in tomato, root knot nematode (Meloidogyne species), sting nematode (Belonolaimus longicaudatus), stubby root nematode (Paratrichodorus and Trichodorus spp.) and lesion nematode (Pratylenchus sp) are important.

Root knot nematode Meloidogyne incognita is one of the world's most catastrophic diseases resulting in loss at different growth stages of tomato. Root knot nematodes are distributed throughout the world, especially in areas with warm or hot climates and short or mild winter and they appear in nursery, open field, poly house and even in green house.

Root knot nematode ( $M$. incognita) is the most dominant species accounting for 64 per cent of total population which is widely prevalent inflicting serious loss to tomato fruit yield (Sasser, 1980). Root knot nematodes are reported to cause losses ranging from 15 to 60 per cent in many vegetable crops such as brinjal, okra, french bean and cowpea (Sasser, 1980; Krishnappa et al., 1992 and Ravichandra, 2008). Apart from M. incognita, other major nematode species causing diseases include $M$. javanica, $M$. arenaria and M. hapla.

They attack more than 2000 species of plants, infecting almost all cultivated plants and reported to reduce world crop production by five per cent in individual fields loss may be even higher (Agrios, 1996). In general, the vegetables and pulses are the good hosts whereas, cereal crops are considered to be the poor hosts of this nematode. Root knot nematodes are a serious problem on vegetables, such as brinjal, okra, tomato, cucurbits, potato and chilli etc. These diseases can be managed by cultural, physical, chemical and biological methods. Among these methods biological control is ecofriendly and cheapest method.

Root knot nematodes devitalize root tips and cause the formation of swellings on roots. These effects not only deprive plants of nutrients but also disfigure and reduce the market value of many root crops. When susceptible plants are infected at the seedling stage, losses are heavy and may result in complete destruction of the crop. Infection on older plants results in slight effects or they may reduce yield considerably (Agrios, 1996).

Above ground symptoms include reduced shoot growth with fewer, small, pale green or yellowish leaves and tend to wilt in warm weather. Blossoms and fruits produced will be less with poor quality. Characteristic symptoms of the disease appear on the underground parts of the plants. Infected plants develop the typical root knot galls that are two to several times larger than the healthy roots. Several infections along the root give the root a rough, clubbed appearance.

More than 80 species of Meloidogyne have been reported from different parts of the world and 13 species have been recorded from India. Among them, Meloidogyne incognita, $M$. javanica, $M$. arenaria, $M$. graminicola, $M$. hapla and $M$. exigua are economically important.

Looking into the severity of root knot nematode infestation on various crops and farmers inclination towards biocontrol agents for the management of nematode diseases, present study has been taken up with specific objectives mentioned below as to study the variability and bioefficacy of Paecilomyces 
lilacinus isolates and its bioefficacy against the root knot nematode.

\section{Materials and Methods}

Present investigations were carried out in kharif season during 2013-2014 at the Main Agricultural Research Station (MARS), University of Agricultural Sciences, and Dharwad. Laboratory experiments were conducted at the Institute of Organic Farming, College of Agriculture, University of Agricultural Sciences, Dharwad, and Karnataka. Various studies were undertaken with the objectives such as, isolation of Paecilomyces sp. and maintenance of pure culture, studies on mass production of Paecilomyces and their shelf life, in vitro and in vivo evaluation of talc based formulation of the bioagent Paecilomyces against root knot nematode. Details of the materials used and the methodology adopted during the course of investigation are presented in this chapter.

\section{General procedure}

\section{Glassware and cleaning}

For all the laboratory studies Corning and Borosil glassware were used. The glass ware were kept submerged overnight in the cleaning solution prepared by dissolving $60 \mathrm{~g}$ of potassium dichromate $\left(\mathrm{K}_{2} \mathrm{Cr}_{2} \mathrm{O}_{7}\right)$ and $60 \mathrm{ml}$ of concentrated sulphuric acid $\left(\mathrm{H}_{2} \mathrm{SO}_{4}\right)$ in one litre of distilled water. Then, they were washed with vim powder followed by rinsing several times in running tap water and finally used when needed for laboratory studies.

\section{Sterilization}

All the glassware used in the studies were sterilized in an autoclave at $1.1 \mathrm{~kg} \mathrm{~cm}$ pressure for $20 \mathrm{~min}$. and then dried in a hot air oven at $60^{\circ} \mathrm{C}$. Media were sterilized at 1.1 $\mathrm{kg} / \mathrm{cm}^{2}$ pressure for $15 \mathrm{~min}$.
An intensive survey was carried out to know the appearance of root knot nematode disease and prevalence of the $P$. lilacinus in different crops in Belgaum, Bagalkot, Haveri, Gadag and Dharwad districts of northern Karnataka. Samples of both healthy and root knot infested soil were collected for isolation of $P$. lilacinus. Each sample was taken separately in polythene bags and tied with a rubber band and labeled immediately. Information pertaining to the locality, crop history, stage of the crop, etc. was also noted. Samples of soil and roots were analysed on the day of collection or after keeping them for a few days under refrigerated conditions. The soil was mixed thoroughly and $200 \mathrm{cc}$ of soil was processed following Cobb's sieving and decanting method (Cobb, 1918) followed by modified Baermann's funnel method (Schindler, 1961).

\section{Isolation of Paecilomyces lilacinus}

The procedure given by Ramakrishna (1989) was followed to isolate P. lilacinus from the collected soil sample. The techniques of serial dilution and purification were carried out as suggested by Sankaram (1961). The Potato dextrose agar media was used for isolation of Paecilomyces lilacinus.

\section{Composition of media}

\section{Potato Dextrose Agar}

Potato Dextrose powder: $20 \mathrm{~g}$

Agar-agar: $20 \mathrm{~g}$

Distilled water: $1000 \mathrm{ml}$

pH: 7.0

Twenty gram potato dextrose powder and agar-agar were dissolved in $800 \mathrm{ml}$ of distilled water. The volume was made up to $1000 \mathrm{ml}$ with distilled water and medium was sterilized at $1.1 \mathrm{~kg}$ per $\mathrm{cm}^{2}$ pressure for 15 $\min$. 
Collection of cultures and maintenance of Meloidogyne incognita nematodes

Root knot infected tomato plants were collected from the farmer's fields during the survey in northern Karnataka in polythene bags and kept in the freezer. Root portion was carefully removed from the soil and washed gently under running tap water. Egg masses were picked and kept for hatching in watch glass with water. After 12-24 hours, hatched juveniles were used to inoculate tomato grown in sterilized soils and (1:1) mixture in greenhouse. These plants served as culture plants. After completion of 3-4 generations of the nematode, the plants were depotted carefully. The root system was washed free of soil, the knots containing egg masses were used to get inoculum of the nematode for further studies.

\section{Extraction of nematodes}

Soil samples of $200 \mathrm{~g}$ was washed thoroughly and processed using combined Cobb's sieving and Bauermann's funnel method. The root knot nematode and other plant parasitic nematodes present in the suspension were identified to genus level by observing different morpho anatomical characters. Their number present in the suspension was determined by taking the average number of nematodes present in five different one mililitre aliquot of nematode suspension.

In vitro studies on bioefficacy of
Paecilomyces lilacinus

\section{Hatching inhibition test}

Egg masses of $M$. incognita were collected from culture plants maintained in nematology net house of the Department of Plant Pathology, Agricultural College Dharwad. Egg masses were picked up and treated with $\mathrm{NaOCl}(1 \%)$ to dissolve the egg matrix and to separate the individual eggs. The known number of eggs of root knot nematodes were put in a watch glass and different concentrations of Paecilomyces and other material as per the treatment were added to these watch glasses and incubated for $96 \mathrm{hrs}$ and microscopic observation on number of eggs hatched was recorded and percentage was calculated.

\section{Juvenile mortality test}

Freshly hatched, 50 active juveniles were counted in a counting dish using a stereo binocular microscope and were carefully transferred to individual vials containing five $\mathrm{ml}$ of each of the different Paecilomyces isolates culture filtrates with same concentrations.

Each treatment was replicated three times and arranged in completely randomized design and incubated at $28 \pm 2^{\circ} \mathrm{C}$. Observations were recorded at 12, 24 and 48 hours after exposure period and per cent mortality was calculated. Known number of root knot nematode juveniles was added in a watch glass and different concentrations of Paecilomyces and other materials as per the treatment were also added to these watch glasses. These watch glass were incubated for $96 \mathrm{hrs}$ and four replication maintained observation on juvenile mortality was recorded and percentage was calculated.

In vivo studies on bioefficacy of Paecilomyces lilacinus

\section{Roll towel method}

Bioefficacy of Paecilomyces and other treatments were carried out based on the seedling vigour index using the standard roll towel method (Anon., 1993). Hundred treated tomato seeds were kept over the presoaked germination paper. 
The seeds were held in zigzag position by placing another presoaked germination paper strip and gently pressed. The polythene sheet along with seeds were then rolled and incubated in growth chamber for seven days. Three replications were maintained for each treatment. Seeds soaked in sterile water served as control. Root and shoot length of individual seedlings were measured and the germination percentage of seeds was also recorded.

The vigour index was calculated by using the formula as described by Baki and Anderson (1973).

Vigour index $(\mathrm{VI})=$ Seedling length $($ Mean root length $x$ mean shoot length) $x$ Germination \%

Ten seedlings were taken randomly from each treatment and their seedling length was recorded.

\section{Results and Discussion}

The results of the present investigation on Mass production of Paecilomyces lilacinus and bioefficacy against root knot nematode caused by Meloidogyne incognita infecting tomato conducted at Department of Plant Pathology, College of Agriculture, UAS, Dharwad and laboratory experiments conducted at Institute of Organic farming UAS, Dharwad during kharif 2013-14 are presented here under.

Survey for the root knot nematode infestation in tomato and presence of Paecilomyces lilacinus

Roving survey was undertaken during kharif, 2013 to assess presence of nematophagous fungi i.e. $P$. lilacinus and observation recorded on incidence of root knot nematode in major tomato, chilli and brinjal growing districts of northern Karnataka viz., Dharwad, Belgaum, Bagalkot, Haveri and Gadag.

\section{Symptomatology}

Root knot nematodes devitalize root tips and cause the formation of swellings on roots. Above ground symptoms include reduced shoot growth with fewer, small, pale green or yellowish leaves and tend to wilt in warm weather. Blossoms and fruits produced will be less in number with poor quality. Characteristic symptoms of the disease appear on the underground parts of the plants. Infected plants develop the typical root knot galls that are two to several times larger than the healthy roots. Several infections along the roots give the roots a rough, clubbed appearance.

Meloidogyne incognita nematodes were identified based on morphological character such as slender stylet, vermiform and pointed tail tip of posterior region.

\section{Isolation and identification of bioagent Paecilomyces lilacinus}

\section{Isolation of bioagent}

The isolation of $P$. lilacinus from the infected and healthy soil sample was made as described in Material and Methods. The pure culture obtained was again subcultured on potato dextrose agar slants and kept in the refrigerator at $5^{\circ} \mathrm{C}$ for further studies.

The Pure culture of Paecilomyces lilacinus was again subculture on malt agar, CTAB+ Oat meal agar. The growth of P. lilacinus was good in both media compared to other.

\section{Identification of bioagent}

The culture was identified based on mycelia characters like septate mycelium, spore 
morphology and the spore size. The conidia were hyaline, single celled, oval to round shaped, and produced on phialides. Based on these characters the bioagent was identified as Paecilomyces lilacinus

\section{Morphological diversity of different isolates of Paecilomyces lilacinus}

Diversity in cultural and morphological characters of $P$. lilacinus was studied on potato dextrose agar media at room temperature $27 \pm 1^{\circ} \mathrm{C}$ as described in "Material and Methods" and the results obtained are presented in table 1 .

During the present study various $P$. lilacinus isolates were coded based on their similarity. Tadakod isolate was coded as PL-1, Dharwad-1 as PL-2 and these two isolates were similar colony characters. Although Bagalkot isolate was similar to them its colony colour was greyish and it was coded as PL-5. Bailahongal, Dharwad-2 and Masankatti isolates sporulated late hence, they were coded as PL-4, PL-3 and PL-7 respectively.

Isolates significantly varied with respect to colony characters, sporulation of the isolate and conidial characters.

Based on the colony characters observed Tadakoda isolate had initially white colony later it turned to pinkish smooth colony. It produced single, round to oval conidia on phailides which sporulated early.

Bailhongal (PL-4) and Bagalkot (PL-5) isolates had similar characters such as initially white coloured colonies later turning to pinkish to greyish colour with single, round to oval conidia on phailides. With respect to sporulation they differed slightly. Sporulation was late in Bailhongal isolate where as it was early in Bagalkot (PL-5) isolate.
Dharwad-1 (PL-2) and Dharwad-2 (PL-3) isolates had similar colony and conidial characters. Initially they had white coloured colonies later they turned to pinkish colour with single round to oval conidia produced on phailides. They differed slightly with respect to sporulation i.e. Dharwad-1 sporulated earlier compared to Dharwad-2 isolate.

Mudhol (PL-6) and Masankatti (PL-7) isolates had similar colony characters, conidia produced were similar and sporulation pattern was same. Initially they had white coloured colonies later on turned to pinkish to greyish colour, single round to oval conidia were produced on phailides. Both the isolates sporulated little late compared to when isolates from other districts.

\section{Bioefficacy of isolates of Paecilomyces lilacinus against root knot nematode}

Artificial inoculation of $M$. incognita nematode to tomato plant was done as explained in "Material and Methods".

Symptoms appeared after completion of life cycle of nematodes such as yellowing of leaf foliage, stunting of plant and galling on the roots.

\section{Egg hatching inhibition test}

From the root knot infected plants eggs were separated from the egg masses. Different isolates of $P$. lilacinus were tested against these eggs. Hatching was significantly reduced in all the treatments with different concentrations of Paecilomyces isolates. Hatching of $M$. incognita eggs increased with decrease in concentration of $P$. lilacinus isolates. The interaction between different isolates and time intervals was significant and it was indicated that an increase in concentration tend to modify the effect of other in a significant manner. 
Different isolates of P.lilacinus were tested for their bioefficacy against root knot nematodes through egg hatching inhibition in different time interval such as 12, 24 and 48 hours. The culture filtrates of $P$. lilacinus at different time intervals significantly inhibited the hatching of eggs (Table 2a).

Inhibition was minimum with $12 \mathrm{hr}$ incubation and it was maximum with $48 \mathrm{hr}$ incubation with all the isolates. The mean per cent egg hatching inhibition has increased from $12 \mathrm{hr}$ to $48 \mathrm{hr}$ incubation. The highest mean egg hatching inhibition was recorded with Mudhol isolate $(89.14 \%)$. Even it had 90.26 per cent inhibition at $48 \mathrm{hr}$ incubation. Tadakoda and Bagalkot isolates had moderate mean inhibition of 81.45 and 81.64 per cent respectively over the control and these isolates were on par with each other (Fig 1a)

The lowest inhibition was observed with Dharwad-2 and Masankatti isolates with 74.33 per cent and 74.88 per cent inhibition over the control and these isolates were on par with each other. In presence of Dharwad-2 and Masankatti isolates root knot nematodes showed maximum per cent egg hatching (25.67 and $25.12 \%$ ) and both are on par to each other indicating their poor performance.

However minimum mean per cent egg hatching was observed with Mudhol isolate $(10.86 \%)$ followed by Tadakoda and Bagalkot isolates (18.55 and $18.54 \%$ ) and both are on par with each other indicating their superiority (Table $2 a$ ).

\section{Juvenile mortality test}

Different isolates of $P$. lilacinus were tested for their bioefficacy against root knot nematodes through juvenile mortality in different time interval such as 12, 24 and 48 hour interval. The culture filtrates of $P$. lilacinus at different time interval significantly increased the mortality of juveniles (Table 3 ).

Minimum mortality was observed with $12 \mathrm{hr}$ incubation and maximum mortality with $48 \mathrm{hr}$ incubation with all the isolates. The mean per cent juvenile mortality has increased from 12 $\mathrm{hr}$ to $48 \mathrm{hr}$ incubation (Fig $1 \mathrm{~b}$ ).

The highest mean juvenile mortality was recorded with Mudhol isolate (75.77 \%). Even it had 80.33 per cent mortality at $48 \mathrm{hr}$ incubation followed by Tadakoda isolate $(66.66 \%)$. Bagalkot isolates had moderate mean juvenile mortality of 64.32 per cent and Dharwad-1 and Dharwad-2 isolates had mean juvenile mortality of 58.30 and 59.09 per cent respectively over the control and these isolates were on par with to each other.

Minimum mortality of 52.55 per cent was observed with Bailhongal isolate followed by Masankatti isolate with 55.66 per cent mortality over the control and these isolates were on par with each other (Table $2 b$ and 3 ).

\section{In vivo studies on bioefficacy of Paecilomyces lilacinus}

\section{Roll towel method}

Various bioagents such as $P$. lilacinus, $T$. harzianum, Lecanicillium lecanii with different concentrations along with treated check such as Carbofuran were used to study their effect on tomato growth parameter viz., Per cent germination, Shoot length $(\mathrm{cm})$, Root length $(\mathrm{cm})$ and also seedling vigour index through roll towel method (Table 4).

In this method, the $P$. lilacinus with $6 \mathrm{~g} / \mathrm{kg}$ seed concentration showed more than 82 per cent seed germination and produced higher shoot (9.07) and root length $(7.17 \mathrm{~cm})$ of tomato seedlings with enhanced vigour index (291.47\%) after seven days. The maximum 
vigour index of 1331.60 was recorded in $P$. lilacinus@6 g/ kg treated seeds with maximum shoot and root length of 9.07 and $7.17 \mathrm{~cm}$, it increases shoot and root length by 145 and 132 per cent over the control respectively. Carbofuran $3 \mathrm{~g} / \mathrm{kg}$ treated seedlings also showed good vigour index (1051.2), shoot $(8.27 \mathrm{~cm})$ and root length $(6.13 \mathrm{~cm})$ with 123.48 and 97.7 per cent increase over the control.

Table.1 Morphological variability of Paecilomyces lilacinus

\begin{tabular}{|c|c|c|c|c|c|}
\hline Districts & Isolates & $\begin{array}{l}\text { Isolate } \\
\text { codes }\end{array}$ & Colony characters & Sporulation & Conidial Character \\
\hline \multirow[b]{2}{*}{ Dharwad } & Tadakoda & PL-1 & Initially white turn & \multirow{3}{*}{ Early sporulation } & \multirow{7}{*}{$\begin{array}{l}\text { Single,round to oval } \\
\text { conidia \& production } \\
\text { of phailides }\end{array}$} \\
\hline & Dharwad -1 & PL-2 & $\begin{array}{l}\text { to light pink, } \\
\text { smooth }\end{array}$ & & \\
\hline Bagalkot & Bagalkot & PL-5 & $\begin{array}{l}\text { Initially white turn } \\
\text { to Pink greyish } \\
\text { colour smooth }\end{array}$ & & \\
\hline Dharwad & Dharwad -2 & PL-3 & \multirow{3}{*}{$\begin{array}{c}\text { Initially white } \\
\text { coloured later turn } \\
\text { to pink colour } \\
\text { smooth }\end{array}$} & \multirow{3}{*}{ Late sporulation } & \\
\hline Belagavi & Bailhongal & PL-4 & & & \\
\hline Bagalkot & Mudhol & PL-6 & & & \\
\hline Haveri & Masankatti & PL-7 & $\begin{array}{l}\text { Initially white turn } \\
\text { to pink to greyish } \\
\text { smooth }\end{array}$ & Late sporulation & \\
\hline
\end{tabular}

Table.2a Bioefficacy of the isolates of Paecilomyces lilacinus on root knot nematode egg hatching inhibition

\begin{tabular}{|c|c|c|c|c|c|}
\hline \multirow{2}{*}{ Isolates } & \multicolumn{4}{|c|}{ Per cent egg hatching inhibition/Time (hr) } & \multirow{2}{*}{$\begin{array}{c}\text { Per cent egg } \\
\text { hatching }\end{array}$} \\
\hline & 12 & 24 & 48 & Mean & \\
\hline Tadakoda (PL-1) & $\begin{array}{c}72.01 \\
(58.10)^{* * *}\end{array}$ & $\begin{array}{c}82.30 \\
(64.94)\end{array}$ & $\begin{array}{c}89.95 \\
(71.52)\end{array}$ & $\begin{array}{c}81.45 \\
(64.49)\end{array}$ & $\begin{array}{c}18.55 \\
(25.51)\end{array}$ \\
\hline Dharwad -1 (PL-2) & $\begin{array}{c}71.77 \\
(57.91)\end{array}$ & $\begin{array}{c}81.22 \\
(64.32)\end{array}$ & $\begin{array}{c}82.30 \\
(65.12)\end{array}$ & $\begin{array}{c}78.81 \\
(62.59)\end{array}$ & $\begin{array}{c}21.19 \\
(27.41)\end{array}$ \\
\hline Dharwad -2 (PL-3) & $\begin{array}{c}68.40 \\
(56.10) \\
\end{array}$ & $\begin{array}{c}74.63 \\
(59.76) \\
\end{array}$ & $\begin{array}{c}77.56 \\
(61.72) \\
\end{array}$ & $\begin{array}{c}74.33 \\
(59.56) \\
\end{array}$ & $\begin{array}{c}25.67 \\
(30.44)\end{array}$ \\
\hline Bailhongal (PL-4) & $\begin{array}{c}73.03 \\
(58.71)\end{array}$ & $\begin{array}{c}79.0 \\
(62.73)\end{array}$ & $\begin{array}{c}80.26 \\
(63.62)\end{array}$ & $\begin{array}{c}77.79 \\
(61.88)\end{array}$ & $\begin{array}{c}22.21 \\
(28.12)\end{array}$ \\
\hline Bagalkot (PL-5) & $\begin{array}{c}73.56 \\
(59.06)\end{array}$ & $\begin{array}{c}82.53 \\
(65.29)\end{array}$ & $\begin{array}{c}86.30 \\
(68.28)\end{array}$ & $\begin{array}{c}81.64 \\
(64.63)\end{array}$ & $\begin{array}{c}18.54 \\
(25.50)\end{array}$ \\
\hline Mudhol (PL-6) & $\begin{array}{c}81.16 \\
(64.28)\end{array}$ & $\begin{array}{c}86.21 \\
(68.20)\end{array}$ & $\begin{array}{c}90.26 \\
(71.81)\end{array}$ & $\begin{array}{c}89.14 \\
(70.76)\end{array}$ & $\begin{array}{c}10.86 \\
(19.24)\end{array}$ \\
\hline Masankatti (PL-7) & $\begin{array}{c}71.60 \\
(57.80)\end{array}$ & $\begin{array}{c}75.06 \\
(60.04)\end{array}$ & $\begin{array}{c}76.93 \\
(61.29)\end{array}$ & $\begin{array}{c}74.88 \\
(59.92)\end{array}$ & $\begin{array}{c}25.12 \\
(30.08)\end{array}$ \\
\hline Mean & 73.07 & 80.14 & 83.36 & 78.85 & 20.31 \\
\hline \multicolumn{2}{|c|}{$\begin{array}{c}\text { Isolates (I) } \\
\text { Time interval } \\
\text { I x Time interval }\end{array}$} & \multicolumn{3}{|c|}{$\begin{array}{c}\text { S.Em.土 } \\
1.21 \\
0.79 \\
2.11\end{array}$} & $\begin{array}{c}\text { CD at } 1 \% \\
4.87 \\
3.19 \\
8.45\end{array}$ \\
\hline
\end{tabular}


Table.2b Mortality of juveniles of root knot nematode by Paecilomyces lilacinus isolates

\begin{tabular}{|c|c|c|c|c|}
\hline \multirow{2}{*}{ Isolates } & \multicolumn{4}{|c|}{ Per cent juvenile mortality /Time (hr) } \\
\cline { 2 - 5 } & $\mathbf{1 2}$ & $\mathbf{2 4}$ & $\mathbf{4 8}$ & Mean \\
\hline \multirow{2}{*}{ Tadakoda (PL-1) } & 62.33 & 66.66 & 71.00 & 66.66 \\
& $(52.14)^{*}$ & $(54.74)$ & $(57.41)$ & $(54.74)$ \\
\hline \multirow{2}{*}{ Dharwad -1 (PL-2) } & 53.33 & 58.26 & 63.33 & 58.30 \\
& $(46.91)$ & $(49.77)$ & $(52.73)$ & $(49.89)$ \\
\hline \multirow{2}{*}{ Dharwad -2 (PL-3) } & 54.66 & 59.33 & 63.3 & 59.09 \\
& $(47.68)$ & $(50.40)$ & $(52.73)$ & $(50.00)$ \\
\hline \multirow{2}{*}{ Bailhongal (PL-4) } & 49.33 & 52.66 & 55.66 & 52.55 \\
& $(44.61)$ & $(46.52)$ & $(48.25)$ & $(46.85)$ \\
\hline \multirow{2}{*}{ Bagalkot (PL-5) } & 59.66 & 63.66 & 69.66 & 64.32 \\
& $(50.57)$ & $(52.93)$ & $(56.58)$ & $(53.58)$ \\
\hline \multirow{2}{*}{ Mudhol (PL-6) } & 71.66 & 75.33 & 80.33 & 75.77 \\
& $(57.85)$ & $(60.25)$ & $(63.70)$ & $(61.20)$ \\
\hline \multirow{2}{*}{ Masankatti (PL-7) } & 53.00 & 55.33 & 58.66 & 55.66 \\
\hline Mean & $(46.72)$ & $(48.06)$ & $(49.92)$ & $(48.75)$ \\
\hline Isolates (I) & 57.71 & 61.60 & 65.99 & 61.79 \\
\hline Time interval & & \multicolumn{5}{|c|}{ CD at $1 \%$} \\
I x Timeinterval & & $0.82 \pm$ & & 2.46 \\
\hline
\end{tabular}

Table.3 Bioefficacy of different isolates of Paecilomyces lilacinus against root knot nematode

\begin{tabular}{|c|c|c|}
\hline Isolates & Per cent egg hatching inhibition & Per cent juvenile mortality \\
\hline Tadakoda (PL-1) & $81.45(64.49)^{*}$ & $66.66(54.74)$ \\
\hline Dharwad-1 (PL-2) & $78.8(62.58)$ & $58.30(49.89)$ \\
\hline Dharwad-2 (PL-3) & $74.33(59.56)$ & $59.09(50.00)$ \\
\hline Bailhongal (PL-4) & $77.78(61.88)$ & $52.55(46.85)$ \\
\hline Bagalkot (PL-5) & $81.64(64.63)$ & $64.32(53.58)$ \\
\hline Mudhol (PL-6) & $89.14(70.76)$ & $75.77(61.20)$ \\
\hline Masankatti (PL-7) & $74.88(59.92)$ & $55.66(48.75)$ \\
\hline S.Em.土 & 0.70 & 2.46 \\
\hline CD at 1\% & 2.98 & 0.82 \\
\hline
\end{tabular}


Table.4 Effect of Paecilomyces lilacinus on plant growth parameters by roll towel method

\begin{tabular}{|c|c|c|c|c|c|c|c|c|c|}
\hline Treatment & $\begin{array}{l}\text { Conc. } \\
\text { (g/kg } \\
\text { seed) }\end{array}$ & $\begin{array}{c}\text { Germination } \\
(\%)\end{array}$ & $\begin{array}{c}\text { Per cent } \\
\text { increase in } \\
\text { germination } \\
\text { over control }\end{array}$ & $\begin{array}{c}\text { Shoot } \\
\text { length } \\
(\mathbf{c m}) \\
\text { at } \\
\text { 7days }\end{array}$ & $\begin{array}{c}\text { Per } \\
\text { cent } \\
\text { increase } \\
\text { in shoot } \\
\text { length } \\
\text { over } \\
\text { control }\end{array}$ & $\begin{array}{c}\text { Root } \\
\text { length } \\
(\mathbf{c m}) \\
\text { at } 7 \\
\text { days }\end{array}$ & $\begin{array}{c}\text { Per } \\
\text { cent } \\
\text { increase } \\
\text { in root } \\
\text { length } \\
\text { over } \\
\text { control }\end{array}$ & $\begin{array}{c}\text { Seedling } \\
\text { vigour } \\
\text { index at } \\
7 \text { days }\end{array}$ & $\begin{array}{c}\text { Per } \\
\text { cent } \\
\text { increase } \\
\text { in } \\
\text { vigour } \\
\text { index } \\
\text { over } \\
\text { control }\end{array}$ \\
\hline $\begin{array}{l}\text { Paecilomyces } \\
\text { lilacinus }\end{array}$ & 2 & 70.33 & 40.66 & 6.0 & 62.16 & 4.87 & 57.09 & 764.40 & 124.48 \\
\hline $\begin{array}{l}\text { Paecilomyces } \\
\text { lilacinus }\end{array}$ & 4 & 75.00 & 50.00 & 7.20 & 94.59 & 5.83 & 88.06 & 977.25 & 187.43 \\
\hline $\begin{array}{l}\text { Paecilomyces } \\
\text { lilacinus }\end{array}$ & 6 & 82.00 & 64.00 & 9.07 & 145.00 & 7.17 & 131.2 & 1331.60 & 291.47 \\
\hline $\begin{array}{l}\text { Trichoderma } \\
\text { harzianum }\end{array}$ & 2 & 66.00 & 32.60 & 5.07 & 37.02 & 4.20 & 35.00 & 611.82 & 79.95 \\
\hline $\begin{array}{l}\text { Trichoderma } \\
\text { harzianum }\end{array}$ & 4 & 70.00 & 40.00 & 6.03 & 62.97 & 5.03 & 62.25 & 774.20 & 127.70 \\
\hline $\begin{array}{l}\text { Lecanicillium } \\
\text { lecanii }\end{array}$ & 2 & 66.00 & 32.00 & 6.00 & 62.16 & 4.40 & 41.19 & 686.40 & 101.88 \\
\hline Carbofuran & 3 & 73.00 & 46.00 & 8.27 & 123.0 & 6.13 & 97.70 & 1051.20 & 209.12 \\
\hline Control & - & 50.00 & 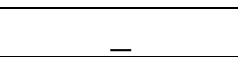 & 3.70 & 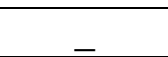 & 3.10 & 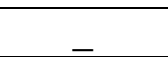 & 340.00 & 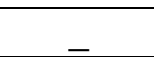 \\
\hline S.Em \pm & & 1.05 & & 012 & & 0.19 & & 6.76 & \\
\hline $\mathrm{CD}$ at $1 \%$ & & 3.15 & & 0.36 & & 0.57 & & 27.93 & \\
\hline
\end{tabular}

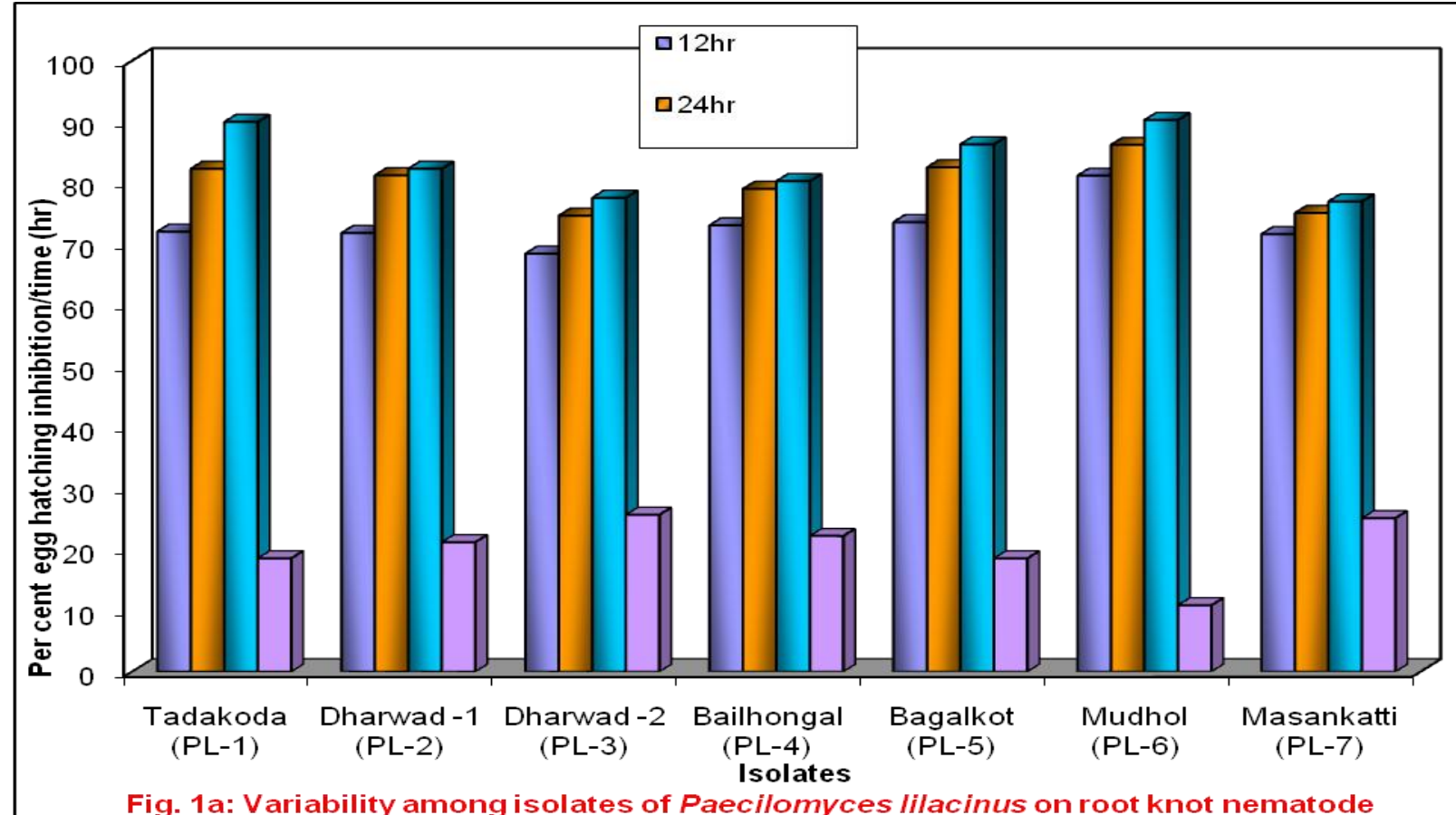



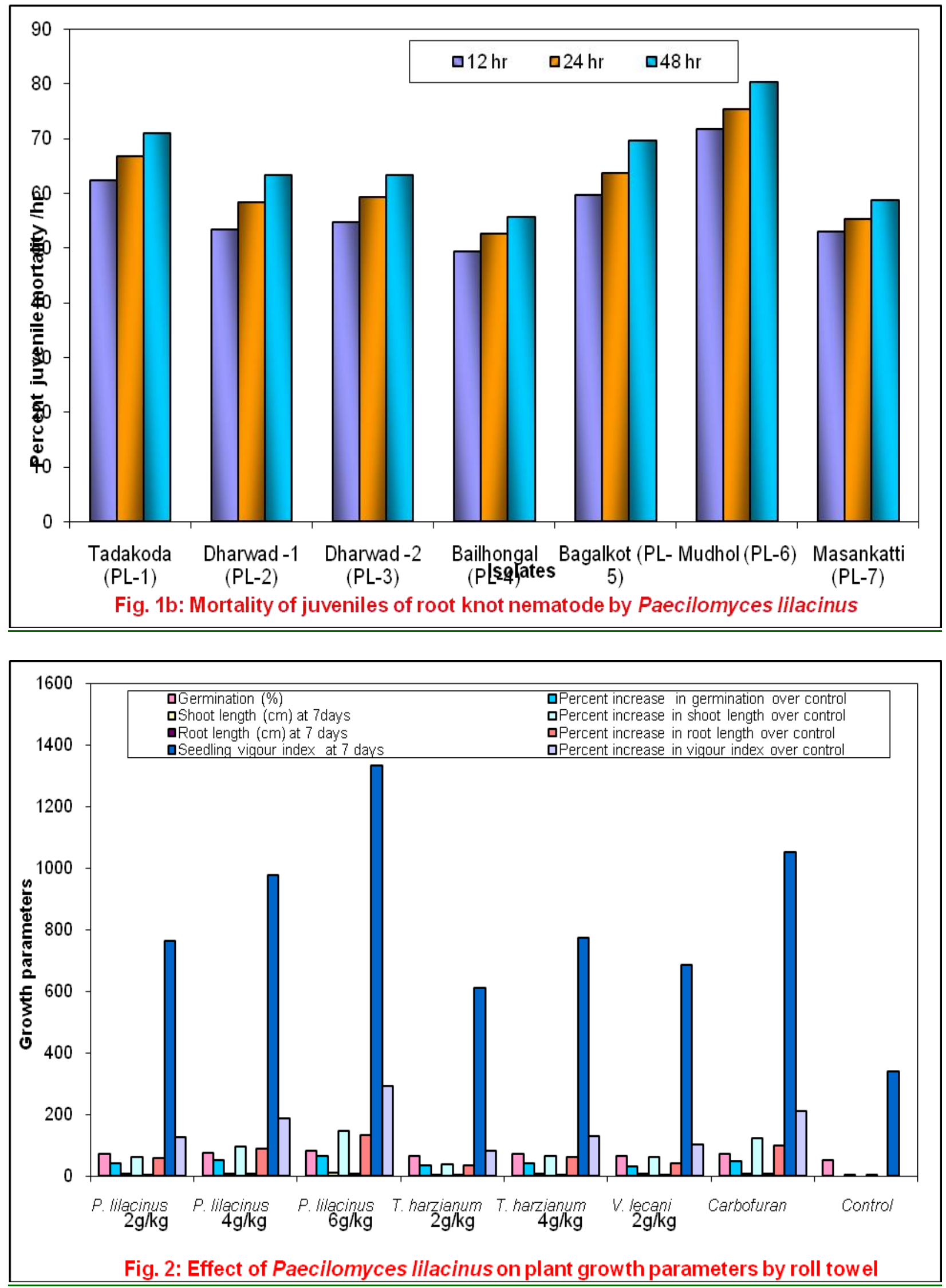
The P. lilacinus@2 $\mathrm{g} / \mathrm{kg}$ seed resulted in 70.33 per cent germination and there was 62.16 per cent increase in shoot length $(6.00 \mathrm{~cm})$ and 57.09 per cent increase in root length $(4.87 \mathrm{~cm})$, vigour index was 764.40 and it increased by 124.48 per cent over the control and it was on par with Trichoderma harzianum @ $4 \mathrm{~g} / \mathrm{kg}$ seeds treated with Trichoderma harzianum at $4 \mathrm{~g} / \mathrm{kg}$ seed had 70.00 per cent seed germination with $6.03 \mathrm{~cm}$ shoot and $5.03 \mathrm{~cm}$ root length with vigour index of 774.20 after seven days compared to control.

Least germination of 66 per cent, least shoot and root length of seedlings with less vigour index of 611.82 was observed in treatment involving Trichoderma harzianum @ $2 \mathrm{~g} / \mathrm{kg}$ followed by Lecanicillium lecanii @ $2 \mathrm{~g} / \mathrm{kg}$ seed with 66.00 per cent germination, shoot, root length of 6.00 and $4.40 \mathrm{~cm}$ respectively with seedling vigour index of 686.40. Untreated control produced seedling with shoot length of 3.70 and root length of 3.10 $\mathrm{cm}$ and seedling vigour index was 340 (Table 4).

Tomato (Solanum lycopersicum Mill) is one of the most important crops and out ranks all other vegetables accept the potato crop in popularity and value in the world.

The modern intensive Agricultural practices have considerably raised the output but created problems like land and environmental degradation and pollution. Besides, this contamination of food products and pesticidal residue in food has caused much panic among the consumers and also the producers. Hence, it is necessary to find out innovative and suitable alternative technology like biological control of pests and diseases. Recently, Paecilomyces lilacinus based different formulations are used for the control of nematode diseases, which is economical, ecofriendly and sustainable in the long run.
Among the different bioagents used in the tomato ecosystem, $P$. lilacinus is extensively used as seed dressing bioagent against many soil borne diseases, however, its usage against foliar diseases is limited.

Among several nematodes of economic importance, root knot nematodes are most widely studied and are commonly found involved in synergistic interactions with wilt inducing fungi and bacteria.

Microbial control of soil borne plant diseases is economically viable and environmental friendly method aimed at sustainable Agriculture. Among the micro-organisms, bioagent are having great promise with the dual advantage of plant growth promotion and plant disease suppression. Recently, $P$. lilacinus spp. has received greater attention of the scientists working towards management of plant parasitic nematodes. Hence, in the present study, an attempt was made to isolate, to screen the different isolates and to study the bioefficacy and antagonistic effect of $P$. lilacinus against Meloidogyne incognita and to study their effect against plant growth parameters through different methods in tomato.

The present investigations were carried out at the Departments of Plant Pathology and Institute of Organic Farming, Agriculture College of Dharwad during 2013-14 and the results obtained are discussed here.

In general, root knot disease caused by Meloidogyne incognita is one of the major constraints to Agriculture. Very less information is available with respect to the occurrence and prevalence of $P$. lilacinus in tomato growing areas of northern Karnataka. Hence, a survey was undertaken to assess the occurrence of $P$. lilacinus in solanaceous crops in Haveri, Belgaum, Dharwad, Gadag and Bagalkot districts. 
Rhizosphere soil samples of tomato crops were collected and processed to isolate $P$. lilacinus which is known to support all types of fungi. Seven isolates were obtained from the rhizosphere of tomato plants around Main Agricultural Research Station, Dharwad and other districts of northern Karnataka.

The findings of the present study revealed that the $P$. lilacinus was more prevalent in Dharwad district followed by Bagalkot district. Root knot nematode incidence was noticed in all the tomato, chilli and brinjal growing locations surveyed.

In Belgaum district, $P$. lilacinus was found in Nayanagar villages of Bailhongal taluka which had rootknot nematode incidence also.

In Munvali and Belavadi villages only root knot nematode incidence was observed whereas, it was not found in Inchal, Sankeshwar, and Yamakanmaradi locations.

In Dharwad district, at three locations viz. MARS dharwad, Devar hubballi and Tadakoda villages both $P$. lilacinus and root knot nematode were observed. However, at Hebsur village only rootknot nematode was observed which indicated natural occurrence of bioagent at places wherever root knot nematode was prevailing.

In Bagalkot district, $P$. lilacinus was isolated from Gaddankeri cross and Mudhol soils whereas, rootknot nematode incidence was found in Gaddankeri cross and Karadi Village of Bagalkot district. At Jamankandi, Lokapur, Ilkal and Kandgal villages of Bagalkot district rootknot nematode incidence was not observed during the survey.

In Haveri district, $P$. lilacinus was found only in Masankatti village of Hangal taluka whereas, root knot nematode was observed in Masankatti, Akkialur and Kakol villages.
However, rootknot nematode incidence was not there in Kaginele, Nagnur and Motebenur villages of Byadgi taluka.

In Gadag district, in none of the locations $P$. lilacinus was found. Whereas, rootknot nematode incidence was observed in Gajendragada and Lakkundi villages.

Similar type of observation were made by Patil et al., (2003) while working with medicinal crop such as Coleus, Long pepper and Ashwagandha. Overall prevalence of nematophagous fungi and disease incidence observed in northern Karnataka from flowering to fruiting stage. The prevalence of the nematophagous fungi was more in Dharwad district followed by Bagalkot district. Similar studies were conducted by Archana (2012) and she isolated P. lilacinus, Aspergillus spp from $M$. incognita egg masses. Overall 35 locations were surveyed and soils from these locations were used to isolate $P$. lilacinus. However, isolation was possible only from seven locations.

In the present study, all the seven isolates of $P$. lilacinus were further examined for nematicidal activity against $M$. incognita. Similar studies have been conducted by various workers (Owino and waudo 1996: Chen et al., 2000: Imran et al., 2001) who have randomly screened Paecilomyces lilacinus for their antagonistic activity against nematodes and evaluated them for their plant growth promoting activity also (Goswami et al., (2006) and Kumar et al., (2012)

The findings of the present study revealed that the $P$. lilacinus was prevalent in one or other locations of all the districts surveyed. But overall occurrence was more in Dharwad district. The present survey also indicated the prevalence of $M$. incognita in different crops in all the districts surveyed. Invariably Paecilomyces was isolated from all the 
location where root knot incidence was observed indicating its natural occurrence.

Isolates obtained were identified through microscopic observation and they were characterised into different groups based on the colony characters, sporulating habits and conidial characters. Almost all had similar characters of the $P$. lilacinus explained by Samson (1975). Initially colonies were of white colour later on they turned to pink colour with smooth edges sometimes they turn to greyish colour and differ with respected to sporulation. In case of Tadakoda (PL-1), Dharwad-1 (PL-2) and Bagalkot (PL5) isolates early sporulation was observed whereas Bailhongal (PL-4), Dharwad-2 (PL3) Mudhol (PL-6) and Masankatti isolates (PL-7) late sporulation type was observed.

Regarding conidial characters they did not differ much and produced single, round to oval conidia attached to phailides in long chain. The phailides were possessing swollen base with distinct neck. Similar observations were made by Bainer (1907) while working with root knot nematode management in tomato crop.

In the present study, in vitro bioassay with culture filtrates of different isolate of $P$. lilacinus strains at similar concentrations revealed that egg hatching inhibition with an increase in exposure period as well as concentration. Meloidogyne incognita juveniles and eggs were highly vulnerable to the Paecilomyces strains. Among the seven $P$. lilacinus strains tested, all the strains showed significantly higher antinematode action.

Paecilomyces lilacinus significantly inhibited the hatching of M. incognita eggs and Mudhol isolate was more effective in reducing egg hatching when compared to control. Inhibition increased with the increase in the concentration and Mudhol isolate showed maximum egg hatching inhibition at $48 \mathrm{hr}$ incubation and there was increase in juvenile mortality when incubated for $48 \mathrm{hr}$. Similar, studies were conducted by Ghazala et al., (2004) and they also reported significant egg hatching suppression in root knot nematodes by $P$. variotii. Further, they reported that hyphae of $P$. lilacinus and $P$. variotii strains penetrated into the eggs of root knot nematode and destroyed them (Fig. 3a and $3 b)$.

Reduction in hatching, viability of juveniles and eggs of $M$. incognita are induced by secondary metabolite such as protease, paecilotoxin and serine protease which are produced by $P$. lilacinus (Peter et al., 1995). The bioagent infecting eggs of the root knot nematode Meloidogyne incognita suggested the involvement of lytic enzymes such as protease which binds to nematode eggs. They also concluded that the serine protease might play a role in penetration of fungus through the egg shell of nematode (Fig. 3c and 3d).

The juvenile mortality and egg hatching inhibition of $M$. incognita observed in the present study might be due to antibiosis. Similar observation were recorded by Zaki (1994) he opined that the fungal filtrates of $P$. lilacinus inhibited the hatching of $M$. javanica eggs at all the concentrations used when exposed for 48-72 hours (Fig. 4)

\section{References}

Agrios, G. N., 1996, Plant Pathology. $4^{\text {th }}$ Edition, Academic Press, New York, America, p. 812.

Ahuja, S., and Arora, J. S., 1980, Susceptibility of flowering annuals to root nematodes (Meloidogyne incognita) and control of plant parasitic nematodes. Trop. Pest Managt, 26: 293295.

Amala, U., 2012, Mass multiplication of 
entomopathogenic

Paecilomyces lilacinus with solid substrate. J. Biopest., 5 (2):168.

Anonymous, 1993, Proceedings of the international seed testing association, international rules for seed testing. Seed Sci. Technol., 21: 25-30.

Anonymous, 2000, Ann. Rep. (2000-01) Asian vegetable research development, Taiwan, p. 110.

Bainer, G., 1907, Mycotheque de 1'ecole de Pharmacie, XI. Paecilomyces genere nouveae de Mucedinees. Bull. Trimmest. Soc. Medit., 16: 135-136.

Baki, A. A., and Anderson, J. D., 1973, Vigour determination in soybean seed by multiple criteria. Crop Sci., 13: 630633.

Balanchard, D., Lecoq, H. and Pitrat, M., 1992, A colour atlas of cucurbit diseases: Observation, Identification and control. Wiley and sons, New York, p: 304.

Cadioli, M. C., Santiago, D. C., Oliveira, A. D. D., Paes, V. D. S., Arieira, G. D. O. and Baida, F. C., 2009, Effect of isolates of Paecilomyces lilacinus on the development of coffee plantations and on the population of Meloidogyne paranaensis Ciencia. Agrotechologia, 33: 713-720.

Cecilia, A. S., Evelina, A. T. and Lilia, M. A., 2010, Processing of tomato: impact on in vitro bioaccessibility of lycopene and textural properties. J. Sci. Food Agric., 90(10): 1665-1672.

Chandarkala, S., Gangopadhayay and Godara, S. L., 2013, Studies on shelf life of Trichoderma spp and Pseudomonas fluorescence in different formulating materials. Pl. Dis. Res., 28 (1): 53-57

El-Shanshoury, A. E. R., El-Sayed, S. A., Mahmoud, Y. A. G. and Khalefa, D. M., 2005, Evaluation of Pochonia chlamydosporia, Paecilomyces lilacinus and Arthrobotrys dactyloides as biocontrol agents for Meloidogyne incognita under greenhouse condition. Pakistan. J. Bio. Sci., 8: 1511-1516.

Enrique, C., Barker, K. B. and Nelson, L. A., 1989, Growth of isolate of Paecilomyces lilacinus and their efficacy in biological control of Meloidogyne incognita on tomato. $J$. Nematol., 21(2): 164-172.

Ghazala, S. M., Ghashira, B. A. and Dabaj, K. H., 2004, Effect of some fungal isolates on egg-hatching inhibition of root-knot nematodes Meloidogyne spp. under laboratory conditions. Proc. Eighth Arab. Cong. Pl. Pro, 12-16 El-Beida, Libya, p. 133

Gintis, B. O., Morgan, J. G. and Rodriguez, K. R., 1983, Fungi associated with several developmental stages of Heterodera glycine from an Alabana soybean field soil. Nematropica, 13: 221-223.

\section{How to cite this article:}

Anusha, B.G., Shripad Kulkarni and Harlapur, S.I. 2017. Morphological and Biological Variability of Different Isolates of Paecilomyces lilacinus Against Root Knot Nematode in Tomato. Int.J.Curr.Microbiol.App.Sci. 6(10): 1243-1257. doi: https://doi.org/10.20546/ijcmas.2017.610.149 